\title{
Critical Success Factors For Supplier Selection: An Update
}

S. Hossein Cheraghi (E-mail: hossein.cheraghi@wichita.edu), Wichita State University Mohammad Dadashzadeh (E-mail: dadashza@oakland.edu), Oakland University Muthu Subramanian (E-mail: muthu.subramanian@demantra.com), Demantra Inc.

\begin{abstract}
For many organizations effective supplier evaluation and purchasing processes are of vital importance. As the pace of market globalization quickens, the number of potential suppliers and the number of factors to consider when selecting suppliers increases. In this paper we present the critical success factors (CSFs) for supplier selection reported in the literature emanating from the seminal work of Dickson and provide an update based on reviewing more than 110 research papers. Our study indicates significant change in the relative importance of various critical success factors in the research reported during 1966-1990 versus 1990-2001. Increased competition and globalization of markets facilitated by Internet-based technologies have combined to dramatically change the ranking of factors while introducing new criteria to the supplier selection process. Based on the results of this study, we conclude that supplier selection criteria will continue to change based on an expanded definition of excellence to include traditional aspects of performance (quality, delivery, price, service) in addition to non-traditional, evolving ones (just-in-time communication, process improvement, supply chain management).
\end{abstract}

\section{Introduction}

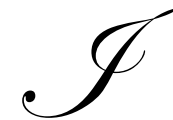

n a 1993 Focus Study from Center for Advanced Purchasing Studies (CAPS), Carter and Narasimhan (1993) concluded: "The research presented in this report demonstrates dramatically that purchasing issues, strategies, and tactics are just as important as marketing, finance, accounting, and operational issues even though purchasing is first in the value chain and 'furthest' from the actual delivery of the product or service to the customer. This is the single most important finding in this study. Purchasing can have a significant impact on quality, customer satisfaction, profitability, and market share." That conclusion has only been strengthened since 1993 by the advent of Internet commerce and its impact on increasing customer expectations leading to today's competitive environment in which margins of error have become, simply stated, razor thin.

The industrial purchasing function remains amongst the most critical activities for ensuring the long-term viability of a firm. Pre-dating the rush to Internet commerce, companies have been pursuing improvements in purchasing along several major trends (Kinney, 2000):

- $\quad$ Outsourcing. In order to specialize in the functions where they enjoy unique core competencies, companies have increasingly sought suppliers to perform manufacturing tasks and services formerly performed inhouse.

- Global Sourcing. In order to lower costs, companies are increasingly looking for low-cost countries not only to outsource some activities, but also to move some purchases from domestic to foreign suppliers.

- Supply Chain Optimization. In order to drastically reduce the amount of inventory being held for contingencies along the entire length of a supply chain, companies are seeking suppliers to achieve true "build to order" capability throughout the supply chain by sharing information and reducing guesswork about the needs, thereby collectively reducing inventory carrying costs, obsolescence, spoilage, and overstocks. 
- $\quad$ Supplier Consolidation. In order to gain volume purchasing power and reduce administrative and coordination costs, companies have been striving to consolidate to fewer suppliers.

Not surprisingly, a common thread in the above approaches to improve purchasing is the supplier selection decision problem. Any mistake in this decision can easily render the approach ineffective and could even adversely affect the stability of the organization in today's turbulent competitive environment with little or no tolerance for errors.

In the US, the total dollar magnitude of purchases by businesses exceeds the gross national product (Tully, 1995). Purchasing transactions typically amount to 55 percent of an organization's revenue. Given that purchasing involves large cash flows and has a significant impact on quality, customer satisfaction, profitability, and market share, the process of selecting suppliers has received considerable attention in purchasing circles. And, as more companies shift their paradigm from a zero sum game of supplier-buyer bargaining power to one based on a win-win proposition for developing long-term relationships aimed at improving coordination of supplier networks throughout the supply chain, the supplier selection problem becomes an increasingly strategic decision confronting the management of the firm.

In this paper we present the critical success factors (CSFs) for supplier selection reported in the literature. Specifically, we re-examine the CSFs reported in the seminal work of Dickson (1966) and provide an update based on reviewing more than 110 research papers. We also posit reasons for the increase or the decrease in the importance of a particular CSF and examine the impact of the Internet on the supplier selection process.

\section{Critical Success Factors For Supplier Selection}

The identification and analysis of criteria for selection and evaluation of vendors has been the focus of attention for many academicians and practitioners. In his seminal work, Dickson (1966) conducted a questionnaire survey mailed to about 300 commercial organizations, primarily manufacturing firms. The purchasing managers of these firms were asked to identify factors that were important for selecting suppliers. His findings were divided into two categories: vendor selection practices by firms and vendor selection practices by individuals.

Table 1 summarizes his results pertaining to factors commonly used to rate potential suppliers by firms. It identifies quality, price, and delivery as the most critical factors in the supplier selection process.

To study vendor selection practices by individual decision makers, he selected four unique purchasing scenarios encompassing markedly different products and situations and a list of 23 factors reported in the purchasing literature as important to the supplier selection decision problem. Each respondent (purchasing manager) was asked to consider each scenario and rate the importance of each of the factors listed using a scale of 0-4 (4 representing extreme importance and 0 indicating slight or no importance). Table 2 depicts the results.

A readily noticeable difference between the two tables is the reduced ranking of service in the latter. This could have been the result of the fact that the selected purchasing scenarios were atypical with regard to service requirements. Indeed, Table 3 points out the influence of the item/service being purchased on the relative importance of various factors in the supplier selection decision problem.

Table 1. Factors Used In Vendor Rating Systems (Dickson, 1966)

\begin{tabular}{|l|c|}
\hline \multicolumn{1}{|c|}{ Factor } & $\begin{array}{c}\text { Percentage Of Systems } \\
\text { Using The Factor }\end{array}$ \\
\hline Quality & 96.6 \\
\hline Price & 93.9 \\
\hline Delivery & 93.9 \\
\hline Service & 81.8 \\
\hline Technical Capability & 63.6 \\
\hline Financial Strength & 51.5 \\
\hline Geographical Location & 42.4 \\
\hline Reputation & 42.4 \\
\hline Reciprocal Arrangements & 15.1 \\
\hline Other Factors & 12.1 \\
\hline
\end{tabular}


Table 2. Aggregate Factor Ratings (Dickson, 1966)

\begin{tabular}{|c|c|c|c|}
\hline Number & Factor & Mean & Relative Importance \\
\hline 1 & Quality & 3.508 & Extreme Importance \\
\hline 2 & Delivery & 3.417 & \multirow{7}{*}{ Considerable Importance } \\
\hline 3 & Performance History & 2.998 & \\
\hline 4 & Warranties \& Claims Policies & 2.849 & \\
\hline 5 & Production Facilities and Capacity & 2.775 & \\
\hline 6 & Price & 2.758 & \\
\hline 7 & Technical Capability & 2.545 & \\
\hline 8 & Financial Position & 2.514 & \\
\hline 9 & Procedural Compliance & 2.488 & \multirow{14}{*}{ Average Importance } \\
\hline 10 & Communication System & 2.426 & \\
\hline 11 & Reputation and Position in Industry & 2.412 & \\
\hline 12 & Desire for Business & 2.256 & \\
\hline 13 & Management and Organization & 2.216 & \\
\hline 14 & Operating Controls & 2.211 & \\
\hline 15 & Repair Service & 2.187 & \\
\hline 16 & Attitude & 2.120 & \\
\hline 17 & Impression & 2.054 & \\
\hline 18 & Packaging Ability & 2.009 & \\
\hline 19 & Labor Relations Record & 2.003 & \\
\hline 20 & Geographical Location & 1.872 & \\
\hline 21 & Amount of Past Business & 1.597 & \\
\hline 22 & Training Aids & 1.537 & \\
\hline 23 & Reciprocal Arrangements & 0.610 & Slight Importance \\
\hline
\end{tabular}

Table 3. Most Important Factors By Situation (Dickson, 1966)

\begin{tabular}{|c|l|l|l|l|}
\hline $\begin{array}{c}\text { Importance } \\
\text { Rank }\end{array}$ & \multicolumn{1}{|c|}{$\begin{array}{c}\text { Case A } \\
\text { Paint }\end{array}$} & \multicolumn{1}{c|}{$\begin{array}{c}\text { Case B } \\
\text { Desks }\end{array}$} & \multicolumn{1}{c|}{$\begin{array}{c}\text { Case C } \\
\text { Computers }\end{array}$} & $\begin{array}{c}\text { Case D } \\
\text { Art Work }\end{array}$ \\
\hline 1 & Quality & Price & Quality & Delivery \\
\hline 2 & Warranties & Quality & Technical Capability & Production Capacity \\
\hline 3 & Delivery & Delivery & Delivery & Quality \\
\hline 4 & Performance History & Warranties & Production Capacity & Performance History \\
\hline 5 & Price & Performance History & Performance History & Communication System \\
\hline
\end{tabular}

Dickson reconfirmed his earlier observation that price was not a consistently important factor in the vendor selection process. Similarly, technical capability, production capacity, and warranties while considered by the respondents to be very important for some of the purchases were also deemed unworthy of much consideration in other instances. He finally concluded that three factors were crucial in the choice of vendors: the ability to meet quality standards, the ability to deliver the product on time, and performance history. He also made a few generalizations about the importance of factors in the vendor selection process. The more complex the product/service being purchased, the more factors are likely to be considered, and in these cases, price is likely to be relatively unimportant. Conversely, in purchases of ordinary products like nuts and bolts, price is generally the primary factor that is considered. Thus he concluded that the nature of the item to be purchased has a major influence on the factors that are considered when selecting a supplier. As such, he doubted the credibility of one universal system for vendor analysis that could be appropriate for all kinds of purchasing decisions. 


\section{Critical Success Factors For Supplier Selection: 1966-1990 And 1990-2001}

Dickson's pioneering work was re-visited by Weber et al. (1991) where 76 articles published between 1966 (year of Dickson's study) and 1990 were categorized based on Dickson's 23 vendor selection criteria. Considering the extensive nature of their study and the structured approach adopted, it was appropriate to extend their results to encompass research on the supplier selection decision problem published between 1990 and 2001. Including the journal articles from Weber et al., 113 articles were reviewed and the findings are presented in this section.

Table 4 presents a list of the journals in which the articles were published. Just as Weber et al. indicated, the majority of them (37\%) appeared in the International Journal of Purchasing and Materials Management. It is noteworthy that relatively less attention has been paid to this topic by operations research and decision science journals.

Table 4. Publication Outlets For Research Papers Reviewed

\begin{tabular}{|c|c|c|c|c|}
\hline Journal & $\begin{array}{c}\text { Number Of } \\
\text { Papers } \\
\text { 1966-1990 } \\
\end{array}$ & & $\begin{array}{c}\text { Number Of } \\
\text { Papers } \\
\text { 1966-1990 } \\
\end{array}$ & \\
\hline Computers and Industrial Engineering & & & 1 & $3 \%$ \\
\hline Computers and Operations Research & 2 & $3 \%$ & 1 & $3 \%$ \\
\hline Decision Sciences & 2 & $3 \%$ & 2 & $5 \%$ \\
\hline European Journal of Operational Research & 1 & $1 \%$ & 1 & $3 \%$ \\
\hline Harvard Business Review & 1 & $1 \%$ & & \\
\hline IIE Transactions & & & 1 & $3 \%$ \\
\hline Industrial Marketing Management & 2 & $3 \%$ & 1 & $3 \%$ \\
\hline Integrated Manufacturing Systems & & & 1 & $3 \%$ \\
\hline Interfaces & 1 & $1 \%$ & & \\
\hline International Journal of Operations and Production Management & 2 & $3 \%$ & 3 & $8 \%$ \\
\hline International Journal of Physical Distribution and Logistics Management & & & 4 & $10 \%$ \\
\hline International Journal of Production Economics & & & 1 & $3 \%$ \\
\hline International Journal of Production Research & 3 & $4 \%$ & & \\
\hline International Journal of Purchasing and Materials Management & 33 & $45 \%$ & 9 & $23 \%$ \\
\hline Journal of Applied Business Research & & & 2 & $5 \%$ \\
\hline Journal of Business Logistics & 3 & $4 \%$ & & \\
\hline Journal of Marketing & 4 & $5 \%$ & & \\
\hline Journal of Marketing Research & 2 & $3 \%$ & & \\
\hline Journal of Operational Research Society & 1 & $1 \%$ & & \\
\hline Journal of Operations Management & 1 & $1 \%$ & 2 & $5 \%$ \\
\hline Journal of Purchasing & 5 & $7 \%$ & & \\
\hline Journal of Retailing & 1 & $1 \%$ & & \\
\hline Journal of Small Business Management & & & 1 & $3 \%$ \\
\hline Journal of Supply Chain Management & & & 3 & $8 \%$ \\
\hline Management Science & 5 & $7 \%$ & & \\
\hline Omega & & & 1 & $3 \%$ \\
\hline Operational Research Quarterly & 1 & $1 \%$ & & \\
\hline Production and Inventory Management Journal & 3 & $4 \%$ & 1 & $3 \%$ \\
\hline Purchasing & & & 1 & $3 \%$ \\
\hline Purchasing and Supply Management & & & 1 & $3 \%$ \\
\hline Supply Chain Management: An International Journal & & & 2 & $5 \%$ \\
\hline
\end{tabular}


Table A in the Appendix categorizes all articles based on the 23 vendor selection criteria identified numerically in Table 2. The articles are listed by author and year of publication. A " 1 " confirms the recognition of a criterion in the supplier selection research reported in the article. The final column named 'Other' indicates the total number of criteria used in the article that cannot be classified by any of Dickson's 23 vendor selection criteria. It is important to note that as stated by Weber et al., this review is entirely based on academic literature while Dickson's study was based on a survey of purchasing agents. Hence any comparisons between the two studies should be done with the realization that the two studies were based on two different 'populations'. (Weber et al., 1991)

From Table A it can be determined that out of 113 papers, 86 papers have considered more than one evaluation criterion. Therefore, $76 \%$ of the papers reviewed consider the supplier selection problem as a multiple criteria decision problem. Table 5 lists the number of articles in which each criterion was addressed and provides a comparison of the factors considered in Weber et al. study and those in this study. Figure 1 presents a graphical comparison of the two studies.

Table 5. Comparison Of Factors: 1966-1990 And 1990-2001

\begin{tabular}{|c|c|c|c|c|c|c|}
\hline \multirow{2}{*}{ Factor } & \multicolumn{2}{|c|}{ 1966-1990 } & \multicolumn{2}{|c|}{ 1990-2001 } & \multicolumn{2}{|c|}{ Overall } \\
\hline & Papers & & Papers & & Papers & \\
\hline Quality & 40 & $54 \%$ & 31 & $79 \%$ & 71 & $63 \%$ \\
\hline Delivery & 45 & $61 \%$ & 30 & $77 \%$ & 75 & $66 \%$ \\
\hline Performance History & 7 & $9 \%$ & 4 & $10 \%$ & 11 & $10 \%$ \\
\hline Warranties \& Claim Policies & 1 & $1 \%$ & 0 & $0 \%$ & 1 & $1 \%$ \\
\hline Production Facilities and Capacity & 25 & $34 \%$ & 10 & $26 \%$ & 35 & $31 \%$ \\
\hline Price & 55 & $74 \%$ & 26 & $67 \%$ & 81 & $72 \%$ \\
\hline Technical Capability & 19 & $26 \%$ & 11 & $28 \%$ & 30 & $27 \%$ \\
\hline Financial Position & 8 & $11 \%$ & 7 & $18 \%$ & 15 & $13 \%$ \\
\hline Procedural Compliance & 2 & $3 \%$ & 2 & $5 \%$ & 4 & $4 \%$ \\
\hline Communication System & 3 & $4 \%$ & 4 & $10 \%$ & 7 & $6 \%$ \\
\hline Reputation and Position in Industry & 9 & $12 \%$ & 1 & $3 \%$ & 10 & $9 \%$ \\
\hline Desire for Business & 2 & $3 \%$ & 0 & $0 \%$ & 2 & $2 \%$ \\
\hline Management and Organization & 10 & $14 \%$ & 7 & $18 \%$ & 17 & $15 \%$ \\
\hline Operating Controls & 5 & $7 \%$ & 0 & $0 \%$ & 5 & $4 \%$ \\
\hline Repair Service & 7 & $9 \%$ & 11 & $28 \%$ & 18 & $16 \%$ \\
\hline Attitude & 9 & $12 \%$ & 5 & $13 \%$ & 14 & $12 \%$ \\
\hline Impression & 4 & $5 \%$ & 2 & $5 \%$ & 6 & $5 \%$ \\
\hline Packaging Ability & 5 & $7 \%$ & 0 & $0 \%$ & 5 & $4 \%$ \\
\hline Labor Relations Record & 3 & $4 \%$ & 1 & $3 \%$ & 4 & $4 \%$ \\
\hline Geographical Location & 15 & $20 \%$ & 2 & $5 \%$ & 17 & $15 \%$ \\
\hline Amount of Past business & 1 & $1 \%$ & 0 & $0 \%$ & 1 & $1 \%$ \\
\hline Training Aids & 3 & $4 \%$ & 0 & $0 \%$ & 3 & $3 \%$ \\
\hline Reciprocal Arrangements & 3 & $4 \%$ & 2 & $5 \%$ & 5 & $4 \%$ \\
\hline
\end{tabular}

Significant changes in relative importance of such factors as Repair Service and Geographical Location for supplier selection can easily be noted in Figure 1. In Table 6, we specifically show the percentage change in relative importance of the 23 criteria considered in Weber et al. study and our study. The negative numbers indicate a decrease in importance. 
Figure 1. Comparison Of Factors: 1966-1990 And 1990-2001

\section{Comparison of Studies}

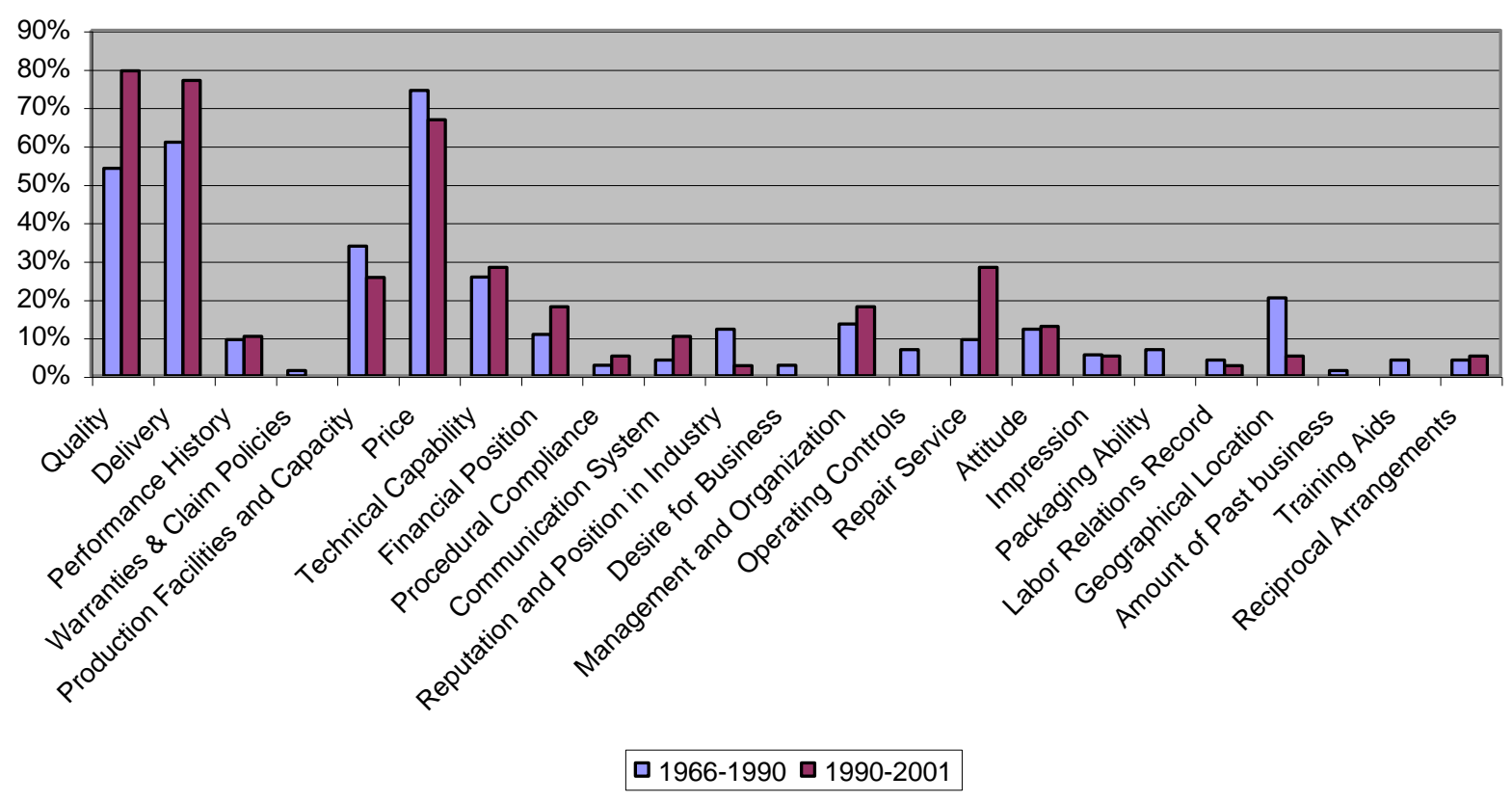

Table 6. Percentage Change In Relative Importance Of Factors In The Two Studies

\begin{tabular}{|l|c|}
\hline \multicolumn{1}{|c|}{ Factor } & \multicolumn{1}{c|}{$\begin{array}{c}\text { Percentage Change in Importance } \\
\text { 1966-1990 versus 1990-2001 }\end{array}$} \\
\hline Repair Service & $198 \%$ \\
\hline Communication System & $153 \%$ \\
\hline Procedural Compliance & $90 \%$ \\
\hline Financial Position & $66 \%$ \\
\hline Quality & $47 \%$ \\
\hline Management and Organization & $33 \%$ \\
\hline Delivery & $26 \%$ \\
\hline Reciprocal Arrangements & $26 \%$ \\
\hline Technical Capability & $10 \%$ \\
\hline Performance History & $8 \%$ \\
\hline Attitude & $5 \%$ \\
\hline Impression & $-5 \%$ \\
\hline Price & $-10 \%$ \\
\hline Production Facilities and Capacity & $-24 \%$ \\
\hline Labor Relations Record & $-37 \%$ \\
\hline Geographical Location & $-75 \%$ \\
\hline Reputation and Position in Industry & $-79 \%$ \\
\hline Warranties \& Claim Policies & $-100 \%$ \\
\hline Desire for Business & $-100 \%$ \\
\hline Operating Controls & $-100 \%$ \\
\hline Packaging Ability & $-100 \%$ \\
\hline Amount of Past business & $-100 \%$ \\
\hline
\end{tabular}


Table 7 provides the current as well as the previous rankings of the different vendor selection criteria. The column 'Current Rank' indicates the position that each criterion holds in this study (based on the number of papers that criterion occurred in) and the column 'Previous Rank' refers to the rank the criterion held in Weber et al. study. The table also includes new criteria that were not present in the original list of 23 (Dickson, 1966).

Table 7. The Present And Past Ranking Of Vendor Selection Criteria

\begin{tabular}{|c|c|c|}
\hline $\begin{array}{c}\text { Current } \\
\text { Rank }\end{array}$ & $\begin{array}{c}\text { Previous } \\
\text { Rank }\end{array}$ & Factor \\
\hline 1 & 3 & Quality \\
\hline 2 & 2 & Delivery \\
\hline 3 & 1 & Price \\
\hline 4 & 10 & Repair Service \\
\hline 5 & 5 & Technical Capability \\
\hline 6 & 4 & Production Facilities and Capacity \\
\hline 7 & 9 & Financial Position \\
\hline 8 & 7 & Management and Organization \\
\hline 9 & New & Reliability \\
\hline 10 & New & Flexibility \\
\hline 11 & 8 & Attitude \\
\hline 12 & 13 & Communication System \\
\hline 13 & 10 & Performance History \\
\hline 14 & 6 & Geographical Location \\
\hline 15 & New & Consistency \\
\hline 16 & New & Long-Term Relationship \\
\hline 17 & 14 & Procedural Compliance \\
\hline 18 & 12 & Impression \\
\hline 19 & 13 & Reciprocal Arrangements \\
\hline 20 & New & Process Improvement \\
\hline 21 & New & Product Development \\
\hline 22 & New & Inventory Costs \\
\hline 23 & New & JIT \\
\hline 24 & New & Quality Standards \\
\hline 25 & New & Integrity \\
\hline 26 & New & Professionalism \\
\hline 27 & New & Research \\
\hline 28 & New & Cultural \\
\hline 29 & 8 & Reputation and Position in Industry \\
\hline 30 & 13 & Labor Relations Record \\
\hline Passé & 11 & Operating Controls \\
\hline Passé & 11 & Packaging Ability \\
\hline Passé & 13 & Training Aids \\
\hline Passé & 14 & Desire for Business \\
\hline Passé & 15 & Amount of Past Business \\
\hline Passé & 15 & Warranties \& Claims Policies \\
\hline
\end{tabular}

\section{Discussion Of Results}

Reliability, Flexibility, Consistency, and Long-Term Relationship are four significant new entrants into the list of critical success factors for supplier selection. On the other hand, Warranties and Claim Policies, Amount of 
Past Business, Desire for Business, and Training Aids are among the factors that have become passé. Considering the change in relative importance of the various factors a number of observations can be made:

\subsection{Quality}

Quality is generally defined as conformance to requirements or fitness to use. But, like a multi-faceted diamond, quality may be perceived through five principal aspects: 1) transcendent quality is an idea, a condition of excellence; 2) product based quality is tied to product attributes; 3) user based quality reflects fitness to use; 4) manufacturing based quality is conformance to requirements; and 5) value based quality is the degree of excellence at an acceptable price. Whatever the perspective, quality has two major components: quality of conformance-quality is defined by the absence of defects; and quality of design-quality is measured by the degree of customer satisfaction with a product's characteristics and features. (APICS, 1999)

In supplying products or services there are three fundamental parameters that determine their saleability. They are price, delivery, and quality. Customers require products and services of a given quality to be delivered by, or be available by, a given time, and to be at a price that reflects value for money. These are the needs of customers. An organization will survive only if it creates and retains satisfied customers and this can only be achieved if the products or services meet customer needs and expectations. While price is a function of cost, profit margin, and market forces, and delivery is a function of the organization's efficiency and effectiveness, quality is determined by the extent to which a product or service successfully serves the purpose of the user during usage (not just at the point of sale). Price and delivery are transient features whereas the impact of quality is sustained long after the attraction or the pain of price and delivery has subsided. Therefore, the fact that quality is on top of the list of critical success factors for supplier selection should not be surprising.

\subsection{Delivery}

Along with quality, another factor that is considered a basic prerequisite for supplier selection is delivery. Even after 36 years since Dickson's study conforming to quality specifications and meeting delivery deadlines remain the most important supplier selection criteria. In a fundamental sense, these form the threshold criteria that buying firms apply to all suppliers before they can be considered as strategic partners in the buyer-supplier relationship (Choi, 1996). They have emerged as order qualifiers to the extent that if suppliers cannot demonstrate acceptable performance in these two areas, they will be dropped as potential candidates during the screening phase itself. One possible explanation for the continuing high ranks that these two criteria receive is that conformance to specifications in these two areas will ensure minimization of disruptions in the buyer's manufacturing operations thereby ensuring uninterrupted production.

\subsection{Repair Service}

Even as late as early 1980s, suppliers wielded the greatest bargaining power in the buyer-seller relationship. Many markets were characterized by having few suppliers practicing mass manufacturing and marketing. However, since the early 1980 s there has been a marked improvement in the bargaining power of the buyer. With customers becoming much more knowledgeable in terms of defining their requirements and because of the increasing competition faced by the suppliers, customers have begun to dictate the terms of purchasing. The companies that used to thrive on mass production, stability, and growth are no longer guaranteed continued success in a world where customers, competition, and change, demand flexibility and quick response. Today, the overriding objective or even prerequisite for any organization to thrive in a competitive marketplace is to focus on customer satisfaction. All other factors being equal, it is inevitable that a buyer will favor the supplier that offers better customer service. Easy accessibility, fast response, flexibility, the technical expertise to support problems, quality of service provided, and above all satisfaction with the product or the service provided are the many dimensions of good customer service. 


\subsection{Technical Capability}

The rapid pace of introduction and deployment of new technologies has contributed to the increased importance of an evaluation of the technical capability of a prospective vendor in the supplier selection decision problem. The buyer is not only concerned about the current technology utilized by the supplier but also about its future technological capability. This includes a supplier's design capability as well as the speed with which it can take an item from the development stage into the production stage. Related to the assessment of future technological capabilities is an evaluation of a potential supplier's ability to participate in, and contribute to, the design of the buying firm's new products. Similarly, the supplier's ability to move fast, so that new products can be introduced more quickly, becomes an important asset for the buying organization.

\subsection{Financial Position}

An assessment of the financial stability and fiscal outlook of the supplier is a factor gaining in importance in the growing trend of forging supplier-buyer partnerships. Both buyers and sellers are looking for partners that are viable, ongoing concerns that will contribute to the relationship both for the present and in the future. A supplier on financially unstable footing will have much more difficulty contributing to the partnership venture, as it must focus its efforts on improving its financial soundness. Hence, both suppliers and buyers are becoming more mindful of the financial position of their potential partners in their decision making (Ellram, 1990).

\subsection{Management and Organization}

The critical success factor of Management and Organization encompasses several intangible elements: management attitude; outlook for the future; feeling of trust; compatibility across levels and functions of buyer and supplier firms; and the supplier's organizational structure and personnel. Of course, one of the most difficult factors to rate with any degree of precision is the feeling of trust. Firms described this as a "gut feel" that the supplier firm will hold up its end of the partnership and the two firms will be able to work together well. The management attitude and outlook for the future is the strategic direction that the supplier firm should take, and its willingness to modify that direction to fit the strategy of the buying firm. Goal congruence is a vital factor because a partnership is designed to be a continuing relationship. While strategies may shift over time, an initial fit between the buyer and the seller in terms of strategic outlook and future plans is seen as a prerequisite to establishing a close, long-term relationship. Top management fit is also seen as critical since top management sets the direction for the firm, and it is likely to set the tone of key relationships.

\subsection{Geographical Location}

With the advances in logistics and information technology, business has transcended geographical boundaries. The globalization of the world economy has resulted in an increase in the number of firms that have shifted their concentration on domestic sourcing to development of supplier bases around the world (Min, 1993). The relaxation of trade barriers and the awareness of the relative strengths of the diverse geographical regions of the world have led to this increased interest in international sourcing. As information technology continues to introduce more advanced means for closer coordination of supply chains, we can anticipate further reduction in the importance of the geographic location of the vendor in the supplier selection decision problem.

\section{The Impact Of The Internet On The Supplier Selection Decision Problem}

A major development since Weber et al conducted their study has been the popularization of the Internet both as a communication medium as well as an outlet for publishing research. As such, we felt that it was important to include Internet-based outlets in this study. To that end, a search was conducted in the websites of leading corporations as well as e-magazines and the results have been tabulated in Table 8. 
Table 8. Critical Success Factors For Supplier Selection Obtained In The Internet Survey

\begin{tabular}{|c|l|c|}
\hline Rank & \multicolumn{1}{|c|}{ Factor } & Number of Occurrences \\
\hline 1 & Price & 10 \\
\hline 2 & Quality & 8 \\
\hline 2 & Technical & 7 \\
\hline 3 & E-Commerce & 4 \\
\hline 4 & Performance History & 4 \\
\hline 4 & Service & 3 \\
\hline 5 & Adaptability & 3 \\
\hline 5 & Financial Stability & 3 \\
\hline 5 & Reliability & 3 \\
\hline 5 & Size & 3 \\
\hline 5 & Reputation & 2 \\
\hline 6 & Flexibility & 2 \\
\hline 6 & Environmental Responsibility & 2 \\
\hline 6 & Lead Time & 2 \\
\hline 6 & Specialization & 2 \\
\hline 6 & Customer Service & 2 \\
\hline 6 & Quality Standards & 2 \\
\hline 6 & Communication & 2 \\
\hline 6 & Technology & 2 \\
\hline 6 & Long-Term Relationship & \\
\hline & & \\
\hline & & \\
\hline & & 2 \\
\hline
\end{tabular}

Although the critical success factors cited are very much consistent with the earlier results from the academic literature, one very important addition is e-procurement and e-commerce. The results of Purchasing Magazine's broad-based survey of purchasing professionals reveal that most industrial purchasing professionals perceive the Internet to be a supply management tool that can save sourcing time, efficiently locate new suppliers, reduce costs, greatly improve communication with suppliers, help track supplier performance, and free them for higher level, more value-added work (Purchasing, 1999). They express little doubt that the Internet will enable them to integrate their entire supply chains and make major contributions to company profitability and competitiveness. They believe that widespread use of e-procurement will enable manufacturing companies to move closer to pull-type demand systems, thereby minimizing inventory carrying costs, speeding up cycle times, and enabling their products to match endusers' needs more closely.

Indeed, Internet-based e-commerce technologies collapse physical distance, accelerating the transition to a truly global economy, which in turn forces businesses to become even more competitive. In a fundamental sense, the Internet provides a foundation upon which most, even all, purchasing activities can be performed and appropriate data about them be captured. As such, today's purchasing managers expect their suppliers to be willing to trade through the web utilizing the full range of possibilities for process improvement made feasible by e-commerce technologies. In fact, according to Brunelli (2000), incumbent suppliers who do not invest in e-commerce technology are more likely to be replaced by suppliers that can or will.

\section{Summary And Conclusions}

The supplier selection problem is of vital importance for operation of every firm because the solution of this problem can directly and substantially affect costs and quality. Indeed, for many organizations effective supplier evaluation and purchasing processes are critical success factors. A great deal of research has been conducted to 
determine what criteria should be used to evaluate suppliers. In practice, any set of criteria must be considered in light of real-life constraints, making the supplier selection a complicated decision problem that involves balancing many tradeoffs and satisfying conflicting desiderata.

From a decision support system perspective, the research on the supplier selection problem can be divided into two parts. First, multi-attribute decision making models that give grades to suppliers on a set of criteria, and then use a weighting scheme to arrive at a supplier score. Second, mathematical programming techniques that model the constraints and an objective function to select the optimal supplier. The grading method is easy and intuitive but remains simplistic in that it does not consider any constraints explicitly. On the other hand, mathematical programming methods accommodate both constraints and supplier selection criteria, but must make restrictive assumptions to reduce inordinate complexity. As such, supplier selection criteria play an integral role in both approaches.

In this paper we considered the criteria for supplier selection reported in the literature. Specifically, we reexamined the criteria reported in the seminal work of Dickson (1966) and provided an update based on reviewing more than 110 research papers. Our study indicated significant change in the relative importance of various critical success factors in the research reported during 1966-1990 versus 1990-2001. Increased competition and globalization of markets facilitated by Internet-based technologies have combined to dramatically change the ranking of factors while introducing new criteria to the supplier selection process. Based on the results of this study, it seems appropriate to conclude that supplier selection criteria will continue to change based on an expanded definition of excellence to include traditional aspects of performance (quality, delivery, price, service) in addition to nontraditional, evolving ones (JIT communication, process improvement, supply chain management).

We also expect further erosion of the ranking of price (the number one vendor selection criterion in the research prior to ours) in future research on the supplier selection problem. Purchasing via the Internet has transformed the processes of buying, selling, and supplier selection. For commodity markets, including high-tech parts and products, electronic auctioning is not only challenging price, but also inducing a profound change in the way purchasing managers work with suppliers. Transparent and rigorously-defined criteria in an electronic auction open up established sourcing relationships to determined, underdog suppliers, and lead to pricing bandwidths heretofore unthinkable in conventional negotiation processes. Because such price reductions in supplies is ultimately passed to customers, eProcurement will drive competitiveness throughout the global supply chain allowing factors other than price to assume greater importance in the supplier selection problem.

\section{References}

1. Akinc, U. "Selecting a set of vendors in a manufacturing environment," Journal of OperationsManagement, 11, pp.107-122, 1993.

2. Ansari, A., Modarress, B. "JIT purchasing: problems and solutions," International Journal of Purchasing and Materials Management, 22, pp. 11-15, 1986.

3. Ansari.A., Modarress, B. "JIT purchasing as a quality and production center," International Journal of Production Research, 26(1), pp. 19-26, 1988.

4. Anthony, T.F., Buffa, F.P. "Strategic purchase scheduling," International .Journal of Purchasing and Materials Management, pp. 27-31, 1977.

5. APICS. APICS Dictionary, Educational society for resource management, 1999.

6. Banerjee, A. "A joint economic lot size model for purchaser and vendor," Decision Sciences, 17(3), pp. 292-311, 1986.

7. Banerjee, A. “A quantity discount pricing model to increase vendor profits," Management Science, 32(11), 1986.

8. Barbarosoglu, G., Yazgac,T. "An application of the Analytic Hierarchy Process to the supplier selection problem," Production and Inventory Management Journal, 38(1), pp. 14-21, 1997.

9. Bender, S.P., Brown, W.R., Isaac, H.M., Shapiro, S.J. "Improving purchasing productivity at IBM with a normative decision support system," Interfaces, 15(3), pp. 106-115, 1985. 
10. Benton, W.C. "Purchase quantity discount procedures and MRP," International Journal of Purchasing and Materials Management, 19, pp.30-34, 1983.

11. Benton, W.C. "Purchase lot sizing research for MRP systems," International Journal of Operations and Production Management, 6(1), pp.5-14, 1985.

12. Benton, W.C. "Multiple price breaks and alternative purchase lot sizing procedures in MRP systems," International Journal of Production Research, 23(5), pp. 1025-1047, 1985.

13. Benton, W.C., Whybark, O.C. "MRP and purchase discounts," Journal of Operations Management, 2(2), pp. 137-143, 1982.

14. Benton, W.C., Krajewski, L. "Vendor performance and alternative manufacturing environments," Decision Sciences, 21, pp. 403-415, 1990.

15. Bernard, P. "Managing vendor performance," Production and Inventory Management Journal, 30(1), pp. 1-7, 1989.

16. Bragg, D.J., Hahn, C.K. "MRP and purchasing," International .Journal of Purchasing and Materials Management, 18, pp. 17-22, 1982.

17. Browning, J.M., Zabriskie, N.B., Huellmantel, A.B. "Strategic purchase planning," International Journal of Purchasing and Materials Management, 19, pp. 19-24, 1983.

18. Brunelli, N. "System providers prepare for the future of e-procurement," Purchasing Online, http://www.manufacturing.net/magazine/purchasing, March 23, 2000.

19. Buffa, P.F., Jackson, M.W. “A goal programming model for purchase planning," International Journal of Purchasing and Materials Management, 19(3), pp. 27-33, 1983.

20. Burton, T.T. "JIT/repetitive sourcing strategies: tying the knot with your suppliers," Production and Inventory Management Journal, 29(4), pp. 38-41, 1988.

21. Cardozo, N.R., Cagley, J. "Experimental study of industrial buyer behavior," Journal of Marketing Research, III, pp. 329-334, 1971.

22. Carter, R. "The seven Cs of effective supplier evaluation,” Purchasing and Supply Management, pp. 44-45, 1995.

23. Carter, J.R., Narasimhan, R. "Purchasing and Materials Management's Role in Total Quality Management and Customer Satisfaction," Center for Advanced Purchasing Studies, 1993.

24. Chakravarthy, K.A., Martin, G.E. "An optimal buyer seller discount pricing model," Computers and Operations Research, 15(3), pp. 271-281, 1988.

25. Chapman, N.S. "JIT supplier inventory: an empirical implementation model," International Journal of Production Research, 27(12), pp. 1993-2007, 1989.

26. Chapman, N.S., Carter, L.P. "Supplier/customer inventory relationships under JIT," Decision Sciences, 21(1), pp. 35-51, 1990.

27. Choi, Y.T., Hartley, L.J. "An exploration of supplier selection practices across the supply chain," Journal of Operations Management, 14, pp. 333-343, 1996.

28. Cooper, S.D. “A total system for measuring delivery performance," International Journal of Purchasing and Materials Management, pp. 22-26, 1977.

29. Croell, C.R. "Measuring purchasing effectiveness," International Journal of Purchasing and Materials Management, 16(2), pp. 22-26, 1980.

30. Crow, E.L., Lindquist,D.J. "Buyers differ in evaluating suppliers," Industrial Marketing Management., 11, pp. 205-214, 1982.

31. Curkovic, S., Handfield, R. "Use of ISO 9000 and Baldridge Award criteria in supplier quality evaluation," International Journal of Purchasing and Materials Management, 32(2), pp. 2-11, 1996.

32. Dad, M., Srikanth, K.N. "Pricing policies for quantity discounts," Management Science, 33(10), pp. 12471252, 1987.

33. Degraeve, Z., Roodhooft, F. "Effectively selecting suppliers using total cost ownership," Journal of Supply Chain Management, 35(1), pp. 5-10, 1999.

34. Dempsey, W.A. "Vendor selection and the buying process," Industrial Marketing Management, 7, pp. 257267, 1978.

35. Dickson, W. Gary. “An analysis of vendor selection systems and decisions," Journal of Purchasing, 2, pp. 5-20, 1966. 
36. Edwards, M.G. "Supplier management evaluation,” Journal of Purchasing, 3(1), pp. 28-41, 1967.

37. Ellram, M.L. "The Supplier selection decisions in strategic partnerships," International Journal of Purchasing and Materials Management, 26(4), pp. 8-14, 1990.

38. Frazier, L.G., Spekman, E.R., O'Neal, R.C. "JIT exchange relationships in industrial marketing," Journal of Marketing, 52(4), pp. 52-67, 1988.

39. Gaballa, A.A. "Minimum cost allocation of tenders," Operational Research Quarterly, 25(3), pp. 389-398, 1974.

40. Ghodsypour, S.H., O'Brien, C. "A decision support system for supplier selection using an integrated analytic hierarchy process and linear programming," International Journal of Production Economics, 5657, pp. 199-212, 1996.

41. Goyal, S.K. "Comment on: a generalized quantity discount pricing model to increase supplier's profit," Management Science, 33(12), pp. 1635-1636, 1987.

42. Gregory, E.R. "Source selection a matrix approach," International Journal of Purchasing and Materials Management, 22(2), pp. 24-29, 1986.

43. Gustin, M.C., Daugherty, J.P., Ellinger, E.A. "Supplier selection decisions in systems/software purchases," International Journal of Purchasing and Materials Management, 33(4), pp. 41-46, 1997.

44. Hahn, C.K., Pinto, P.A., Bragg, D.J. "JIT production and purchasing," International Journal of Purchasing and Materials Management, 19, pp. 2-10, 1983.

45. Hahn, C.K., Kim, K.H., Kim, J.S.. “Costs of competition: implications for purchasing strategy,” International Journal of Purchasing and Materials Management, pp. 2-7, 1986.

46. Hakansson, H., Wootz, B. "Supplier selection in an international environment-an experimental study," Journal of Marketing Research, XII, pp. 46-51, 1975.

47. Hinkle, C.L., Robinson, P.J., Green, P.E. "Vendor evaluation using cluster analysis," Journal of Purchasing, pp. 49-58, 1969.

48. Hirakubo, N., Kublin, M. "The relative importance of supplier selection criteria: the case of electronic components procurement in Japan," International Journal of Purchasing and Materials Management, 34(2), pp. 19-24, 1998.

49. Ho, C., Carter, L.P. "Using vendor capacity planning in supplier evaluation," International Journal of Purchasing and Materials Management, 24(1), pp. 23-30, 1988.

50. Houshyar, A., Lyth, D. “A systematic supplier selection procedure," Computers and Industrial Engineering, 23(1-4), pp. 173-176, 1992.

51. Hwang, H., Moon, H.D., Shin, W.S. "An EOQ model with quantity discounts for both purchasing price and freight costs," Computers and Operation Research, 17(1), pp. 73-78, 1990.

52. Jackson, G.C. "JIT production: implications for logistics managers," Journal of Business Logistics, 4(2), pp. 1-19, 1983.

53. Jacobson, R., Aaker, A.D. “The strategic role of product quality,” Journal of Marketing, 51(4), pp. 31-44, 1987.

54. Jayaraman, V., Srivastava, R., Benton, W.C. "Supplier selection and Order quantity allocation: a comprehensive model," Journal Of Supply Chain Management, 35(2), pp. 50-57, 1999.

55. Jordan, P.C. "Purchasing decisions considering future price increases: an empirical approach," International Journal of Purchasing and Materials Management, 23, pp. 25-30, 1987.

56. Karpak, B., Kasuganti, R.R., Kumku, E. "Multi-objective decision making in supplier selection: an application of visual interactive goal programming," Journal of Applied Business Research, 15(2), pp. 57$71,1997$.

57. Kingsman, G.B. "Purchasing raw materials with uncertain fluctuating prices," European Journal of Operational Research, 25, pp. 358-372, 1986.

58. Kinney, S. “An Overview of B2B and Purchasing Technology," http://www.freemarkets.com, 2000.

59. Kraljic, P. "Purchasing must become supply management," Harvard Business Review, 61(5), pp. 109-117, 1983.

60. Krause, R.D., Ellram, M.L. "Success factors in supplier development," International Journal of Physical Distribution and Logistics Management, 27(1), pp. 39-51, 1997. 
61. Krishnan, H. "Supplier selection practicesamong small firms in the United States: testing three modes," Journal of Small Business Management, 39(3), pp. 259-271, 2001.

62. LaForge, R. L. "MRP Lot sizing with multiple discounts," Computers and Operations Research, 12(6), pp. 579-587, 1985.

63. Lamberson, R.L., Diederich, D., Wuori, J. "Quantitative vendor evaluation," International Journal of Purchasing and Materials Management, 12(1), pp. 19-28, 1976.

64. Lambert, M.D., Adams, J. Ronald, Emmelhainz, A.M. "Supplier selection criteria in the health care industry: a comparison of importance and performance," International Journal of Purchasing and Materials Management, 33(1), pp. 16-22, 1997.

65. Lamm, D.V., Vose, L.C. "Seller pricing strategies: a buyer's perspective," International Journal of Purchasing and Materials Management, 24(3), pp. 9-13, 1988.

66. Lee, H.L., Rosenblatt, M.J. "A generalized quantity discount pricing model to increase supplier's profits," Management Science, 32(9), pp. 1177-1185, 1986.

67. Lehmann, R.D., O'Shaugnessy, J. "Difference in attribute importance for different industrial products," Journal of Marketing, 38(1), pp. 36-42, 1974.

68. Levy, M., Cron, W., Novack, R. “A DSS for determining a quantitative discount pricing policy,” Journal of Business Logistics, 6(2), pp. 110-141,1985.

69. Li, C.C., Fun, Y.P., Hung, J.S. "A new measure for supplier performance evaluation,” IIE Transactions, 29(9), pp.753-758, 1997.

70. Mandal, A., Deshmukh, S.G. "Vendor selection using interpretive structural modeling," International Journal of Operations and Production Management, 14(6), pp. 52-59, 1993.

71. Manoochehri, G. H. "Suppliers and the JIT concept," International Journal of Purchasing and Materials Management, pp. 16-21, 1984.

72. Markowski, C.A., Markowski, E.P. "An alternative criterion for the quantity discount decision," International Journal of Purchasing and Materials Management, 24(1), pp. 31-34, 1988.

73. Masella, C., Rangone, A. "A contingent approach to the design of vendor selection systems for different types of co-operative customer/supplier relationships," International Journal of Operations \& Production Management, 20(1), pp. 70-84, 2000.

74. Mazurak, R.E., Rao, S.R., Scotton, D.W. "Spreadsheet software applications in purchasing," International Journal of Purchasing and Materials Management, pp. 8-16, 1985.

75. McFillen, J.M., Reck, R.R., Benton, W.C. "An experiment in purchasing negotiations," International Journal of Purchasing and Materials Management, 19, pp. 2-8, 1983.

76. McGinnis, M.A., Hollon, C.J. "Packaging: organization, objectives and interactions," Journal of Business Logistics, 1(1), pp. 1-61, 1978.

77. Min, H. "International supplier selection: a multi-attribute utility approach," International Journal of Physical Distribution and Logistics Management, 24(5), pp. 24-33, 1993.

78. Mohanty, R.P., Deshmukh, S.G. "Use of Analytic Hierarchic Process for evaluating sources of supply," International Journal of Physical Distribution and Logistics Management, 23(3), pp. 22-28, 1993.

79. Monahan, J.P. "A quantity discount pricing model to increase vendor profits," Management Science, 30(6), pp. 720-726, 1984.

80. Monczka, M.R., Giunipero, C.L., Reck, F.R. "Perceived importance of supplier information," International Journal of Purchasing and Materials Management, 17(1), pp. 21-29, 1981.

81. Monczka, R.M., Trecha, S.J. “Cost-based supplier performance evaluation," International Journal of Purchasing and Materials Management, 24(1), pp. 2-7, 1988.

82. Moore, D.L., Fearon, H.E. "Computer-assisted decision making in purchasing," Journal of Purchasing, 9(4), pp. 5-25, 1973.

83. Motwani, J., Youssef, M., Kathawala, Y., Futch, E. "Supplier selection in developing countries: a model development," Integrated Manufacturing Systems, 10(3), pp. 154-161, 1999.

84. Mummalaneni, V., Dubas, M.K., Chao, C. "Chinese purchasing managers' preferences and trade offs in supplier selection and performance evaluation," Industrial Marketing Management, 25, pp. 115-124, 1996.

85. Narasimhan, R. "An analytical approach to supplier selection," International Journal of Purchasing and Materials Management, 19, pp. 27-32, 1983. 
86. Narasimhan, R., Stoynoff, L.K. “Optimizing aggregate procurement allocation decisions," International Journal of Purchasing and Materials Management, 22, pp. 23-30, 1986.

87. Newman, R.G. "Insuring quality: purchasing's role," International Journal of Purchasing and Materials Management, 24(3), pp. 14-20, 1988.

88. Newman, R.G. “The buyer-supplier relationship under JIT," Production and Inventory Management, 29(2), pp. 45-50, 1988.

89. Newman, R.G., Scodro, J. "Price analysis for negotiation," International Journal of Purchasing and Materials Management, 24(1), pp. 8-14, 1988.

90. Nydick, L.R., Hill, P.R. "Using the AHP to structure the supplier selection procedure," International Journal of Purchasing and Materials Management, 28(2), pp. 31-36, 1992.

91. Pan, C.A. "Allocation of order quantity among suppliers," International Journal of Purchasing and Materials Management, 25(3), pp. 36-39, 1989.

92. Payne, H.L. "Development of a supplier evaluation technique utilizing financial information," Journal of Purchasing, 6(4), pp. 21-34, 1970.

93. Porter, M.A. “Audits under fire,” Purchasing, 113, pp. 50-55, 1992.

94. Purchasing Online. http://www.manufacturing.net/magazine/purchasing. 1999.

95. Roberts, B.J. "A vendor delivery rating model," International Journal of Purchasing and Materials Management, pp. 12-16, 1978.

96. Ronen, B., Trietsch, D. “A DSS for purchasing management of large projects," International Journal of Purchasing and Materials Management, 36(6), pp. 882-890, 1988.

97. Rubin, A.P., Dilts, M.D., Barron, A.B. "Economic order quantities with quantity discounts," Decision Sciences, 14, pp. 270-281, 1983.

98. Sheth, N.J. “A model of industrial buyer behavior,” Journal of Marketing, 37(4), pp. 50-56, 1973.

99. Shore, B., “A micro-computer based purchasing Information system," International Journal of Purchasing and Materials Management, pp. 18-22, 1981.

100. Smytka, L.D., Clemens, W.M. "Total cost supplier selection model: a case study," International Journal of Purchasing and Materials Management, 29(1), pp. 42-49, 1993.

101. Soukoup, R.W. "Supplier selection strategies," International Journal of Purchasing and Materials Management, 23(1), pp. 7-11, 1987.

102. Thompson, N.K. "Scaling evaluative criteria and supplier performance estimates in weighted point prepurchase decision models," International Journal of Purchasing and Materials Management, 27(1), pp. 2736, 1991.

103. Timmerman, E. “An approach to vendor performance evaluation," International Journal of Purchasing and Materials Management, 22(4), pp. 2-8, 1987.

104. Tracey, M., Chong, L.T. "Empirical analysis of supplier selection and involvement, customer satisfaction, and firm performance," vendors to employ," Supply Chain Management: An International Journal, 6(4), pp. 174-188, 2001.

105. Treleven, M., "Single sourcing: a management tool for the quality supplier," International Journal of Purchasing and Materials Management, 23, pp. 19-24, 1987.

106. Tullous, R., Utecht, L.R. "A decision support system for integration of vendor selection task," Journal of Applied Business Research, 10(1), pp. 132-143, 1994.

107. Tully, S. "Purchasing's new muscle," Fortune, 131(3), pp.75-84.

108. Turner, I. “An independent system for the evaluation of contract tenders," Journal of Operational Research Society, 39(6), pp. 551-561, 1988.

109. Verma, R., Pullman, E.M. “An analysis of the supplier selection process," Omega, 26(6), pp. 739-750, 1998.

110. Vokurka, J.R., Choobineh, J., Vadi,L. "A prototype expert system for the evaluation and selection of potential suppliers," International Journal of Operations and Production Management, 16(12), pp. 106$127,1996$.

111. Vonderembse, A.M., Tracey, M. "The impact of supplier selection criteria and supplier involvement on manufacturing performance,” Journal of Supply Chain Management, 35(3), pp. 33-39, 1999. 
112. Wagner, J., Ettenson, R., Parrish, J. "Vendor selection among retail buyers: an analysis by merchandise," Journal of Retailing, 65(1), pp. 58-79, 1989.

113. Weber, C.A., Current, J.R., Benton, W.C. "Vendor selection criteria and methods," European Journal of Operational Research, 50, pp. 2-18, 1991.

114. Weber, C.A., Current, J.R. "A multiobjective approach to vendor selection," European Journal of Operational Research, 68, pp. 173-184, 1991.

115. Weber, C.A., Ellram, M.L. "Supplier selection using multiobjective programming: a decision support system approach," International Journal of Physical Distribution and Logistics Management, 23(2), pp. 3$14,1993$.

116. Weber, C.A., Current, J., Desai, A. "An optimization approach to determining the number of vendors to employ," Supply Chain Management: An International Journal, 5(2), pp. 90-98, 2000.

117. Wieters, C.D. "Influences on the design and use of vendor performance rating systems," International Journal of Purchasing and Materials Management, 12(4), pp. 31-35, 1976.

118. Willis, T.H., Huston, C.R. "Vendor requirements and evaluation in a JIT environment," International Journal of Operations and Production Management, 10(4), 1989.

119. Wilson, J.E., "The relative importance of supplier selection criteria: a review and update," International Journal of Purchasing and Materials Management, 30(3), pp. 35-41, 1994.

120. Wind, Y., Green, P., Robinson, J.P. "The determinants of vendor selection: the evaluation function approach," Journal of Purchasing, 4(3), 1968.

\section{Appendix}

Table A. Classification Of Research Papers Based On Dickson's 23 Criteria

\begin{tabular}{|c|c|c|c|c|c|c|c|c|c|c|c|c|c|c|c|c|c|c|c|c|c|c|c|c|c|}
\hline Author(s) & Year & 1 & 2 & 3 & 4 & 5 & 6 & 7 & 8 & 9 & 10 & 11 & 12 & 13 & 14 & 15 & 16 & 17 & 18 & 19 & 20 & 21 & 22 & 23 & Other \\
\hline Akinc & 1993 & 1 & 1 & & & & 1 & & & & & & & & & & & & & & & & & & \\
\hline Ansari et al & 1986 & 1 & 1 & & & & 1 & & & & & & & & & & 1 & & & & 1 & & & & \\
\hline Ansari et al & 1988 & 1 & 1 & & & & 1 & & & & & & & & & & 1 & & 1 & & 1 & & & & \\
\hline Anthony et al & 1977 & & 1 & & & & 1 & & & & & & & & & & & & & & & & & & \\
\hline Banerjee & 1986 & & & & & & 1 & & & & & & & & & & & & & & & & & & \\
\hline Banerjee & 1986 & & 1 & & & & 1 & & & & & & & & & & & & & & & & & & \\
\hline Barbarosoglu et al & 1997 & 1 & 1 & & & 1 & 1 & 1 & 1 & & & & & 1 & & & 1 & & & & & & & & 3 \\
\hline Bender et al & 1985 & 1 & 1 & & & 1 & 1 & & & & & & & & & & & & & & & & & & \\
\hline Benton & 1983 & & & & & & 1 & & & & & & & & & & & & & & & & & & \\
\hline Benton & 1985 & & & & & & 1 & & & & & & & & & & & & & & & & & & \\
\hline Benton & 1985 & & & & & & 1 & & & & & & & & & & & & & & & & & & \\
\hline Benton et al & 1982 & & & & & & 1 & & & & & & & & & & & & & & & & & & \\
\hline Benton et al & 1990 & 1 & 1 & & & & & & & & & & & & & 1 & & & & & & & & & \\
\hline Bernard & 1989 & 1 & 1 & & & & & & & & & & & 1 & & 1 & & & & & & & & & \\
\hline Bragg et al & 1982 & & 1 & & & 1 & & & & & & & & & & & & & & & & & & & \\
\hline Browning et al & 1983 & & 1 & & & 1 & 1 & 1 & & & & & & & & & & & & & & & & & \\
\hline Buffa et al & 1983 & 1 & 1 & 1 & & 1 & & & & & & & & & & & & & & & & & & & \\
\hline Burton & 1988 & 1 & 1 & & & 1 & 1 & 1 & & & & & & 1 & 1 & & & & 1 & & 1 & & 1 & & \\
\hline Cardozo et al & 1971 & 1 & 1 & & & & 1 & & & & & 1 & & & & & & & & & 1 & & & & \\
\hline Carter & 1995 & & & & & 1 & 1 & & 1 & & & & & & & & 1 & & & & & & & & 2 \\
\hline Chakravarthy et al & 1988 & & & & & & 1 & & & & & & & & & & & & & & & & & & \\
\hline Chapman & 1989 & 1 & 1 & & & 1 & & & & & & & & & & & & & & & & & & & \\
\hline Chapman et al & 1990 & 1 & 1 & & & & & & & & & & & & & & & & & & & & & & \\
\hline Choi et al & 1996 & 1 & 1 & & & & & 1 & & & 1 & & & & & 1 & & 1 & & & & & & & 3 \\
\hline Cooper & 1977 & & 1 & & & & & & & & & & & & & & & & & & & & & & \\
\hline
\end{tabular}




\begin{tabular}{|c|c|c|c|c|c|c|c|c|c|c|c|c|c|c|c|c|c|c|c|c|c|c|c|c|}
\hline Croell & 1980 & 1 & 1 & & & & & & & & & & & & & & & & & & & & & \\
\hline Crow et al & 1982 & 1 & 1 & & & & & 1 & & & & & & & & & & & & & & & & \\
\hline Curkovic et al & 1996 & 1 & & & & & & & & & & & & & & & & & & & & & & 1 \\
\hline Dad et al & 1987 & & & & & & 1 & & & & & & & & & & & & & & & & & \\
\hline Degraeve et al & 1999 & & 1 & & & 1 & 1 & & & & & & & & & & & & & & & & & \\
\hline Dempsey & 1978 & 1 & 1 & 1 & & 1 & 11 & 11 & \begin{tabular}{l|l}
1 & 1
\end{tabular} & 11 & 1 & 1 & 1 & 1 & 1 & 1 & & 1 & 1 & 1 & & 1 & & \\
\hline Dickson & 1966 & 1 & 1 & 1 & 1 & 1 & 11 & 11 & \begin{tabular}{l|l}
1 & 1
\end{tabular} & 11 & 1 & \begin{tabular}{l|l}
1 & 1
\end{tabular} & 11 & 1 & 1 & 1 & 1 & 1 & 1 & 1 & 1 & 1 & 1 & \\
\hline Edwards & 1967 & & & & & & & & & & & & 1 & & & & & & & & & & & \\
\hline Ellram et al & 1990 & & & & & & & 11 & 1 & & & & 1 & & & & & & & & & & & \\
\hline Frazier et al & 1988 & 1 & 1 & & & & 11 & 1 & & & & & 1 & & & & & & & & & & & \\
\hline Gaballa & 1974 & & & & & 1 & 1 & & & & & & & & & & & & & & & & & \\
\hline Ghodyspour et al & 1996 & 1 & 1 & & & 1 & 1 & & & & & & & & & & & & & & & & & \\
\hline Goyal & 1987 & & & & & & 1 & & & & & & & & & & & & & & & & & \\
\hline Gregory & 1986 & 1 & 1 & & & 1 & 11 & 1 & & & & & & & & & & & & 1 & & & & \\
\hline Gustin et al & 1997 & 1 & & & & & 1 & & 1 & 1 & & & & & & & & & & & & & & 2 \\
\hline Hahn et al & 1983 & 1 & 1 & & & 1 & 1 & & & & & & & & & & & & & & & & & \\
\hline Hahn et al & 1986 & 1 & 1 & & & 1 & 11 & 1 & & & & & & & & & & & & 1 & & & & \\
\hline Hakansson et al & 1975 & 1 & & & & 1 & 1 & & & & & & & & & & & & & & & & & \\
\hline Hinkle et al & 1969 & 1 & 1 & & & & 11 & 1 & & & & & & & & & & & & & & & & \\
\hline Hirakubo et al & 1998 & 1 & 1 & & & & 11 & 1 & & & & & & & & & & & & 1 & & & 1 & \\
\hline Ho et al & 1988 & & & & & 1 & & & & & & & & & & & & & & & & & & \\
\hline Houshyar et al & 1992 & 1 & 1 & & & & 1 & & & & & & & & & & & & & & & & & \\
\hline Hwang et al & 1990 & & & & & & 1 & & & & & & & & & & & & & & & & & \\
\hline Jackson & 1983 & 1 & 1 & & & & & & & & & & & & & 1 & & & & 1 & & & & \\
\hline Jacobson et al & 1987 & 1 & & & & & & & & & & & & & & & & & & & & & & \\
\hline Jayaraman et al & 1999 & 1 & 1 & & & 1 & & & & & & & & & & & & & & & & & & \\
\hline Jordan & 1987 & & & & & & 1 & & & & & & & & & & & & & & & & & \\
\hline Karpak et al & 1997 & 1 & 1 & & & & 1 & & & & & & & & 1 & & & & & & & & & \\
\hline Kingsman & 1986 & & & & & & 1 & & & & & & & & & & & & & & & & & \\
\hline Kraljic & 1983 & 1 & 1 & & & 1 & & 1 & & & & & & & & & & & & & & & & \\
\hline Krause et al & 1997 & 1 & 1 & & & & & & & & & & & & & & & & & & & & & \\
\hline Krishnan & 2001 & & & & & 1 & & & & & & 1 & 1 & & & 1 & 1 & & 1 & & & & 1 & \\
\hline LaForge & 1985 & & & & & & 1 & & & & & & & & & & & & & & & & & \\
\hline Lamberson et al & 1976 & 1 & 1 & 1 & & 1 & 11 & 11 & 1 & & & & 1 & & & & & & & & & & & \\
\hline Lambert et al & 1997 & 1 & 1 & & & & & 1 & & 1 & 1 & & 1 & & 1 & & & & & & & & & 1 \\
\hline Lamm et al & 1988 & & & & & & 1 & & & & & & & & & & & & & & & & & \\
\hline Lee et al & 1986 & & & & & & 1 & & & & & & & & & & & & & & & & & \\
\hline Lehmann et al & 1974 & & 1 & & & & 1 & & & & & 1 & & & & & & & & & & & & 2 \\
\hline Levy et al & 1985 & & & & & & 1 & & & & & & & & & & & & & & & & & \\
\hline Li et al & 1997 & 1 & 1 & & & & 1 & & & 1 & 1 & & & & & & & & & & & & & 1 \\
\hline Mandal et al & 1993 & 1 & 1 & & & 1 & 11 & 1 & 1 & & & & 1 & & & 1 & & & & & & & & \\
\hline Manoochehri & 1984 & 1 & 1 & & & & 1 & & & & & & & & & 1 & & & & 1 & & & & \\
\hline Markowski et al & 1988 & & & & & & 1 & & & & & & & & & & & & & & & & & \\
\hline Masella et al & 2000 & & & 1 & & & & 1 & & & & & & & & & & & & & & & & 1 \\
\hline Mazurak et al & 1985 & 1 & 1 & & & & 11 & 1 & & & & & & & & & & & & & & & & \\
\hline McFillen et al & 1983 & 1 & 1 & & & & 1 & & & & & & & & 1 & & & & & & & & & \\
\hline McGinnis et al & 1978 & & & & & & & & & & & & & & & & 1 & & & & & & & \\
\hline Min & 1993 & 1 & 1 & & & 1 & & & 1 & & & & 1 & & & & & & & & & & & 1 \\
\hline Mohanty et al & 1993 & 1 & 1 & & & & 1 & & & & & & & & 1 & & & & & & & & & \\
\hline Monahan & 1984 & & & & & & 1 & & & & & & & & & & & & & & & & & \\
\hline Monczka et al & 1981 & 1 & 1 & 1 & & 1 & 1 & & 1 & & & 1 & & 1 & & & & & 1 & 1 & & & & \\
\hline
\end{tabular}




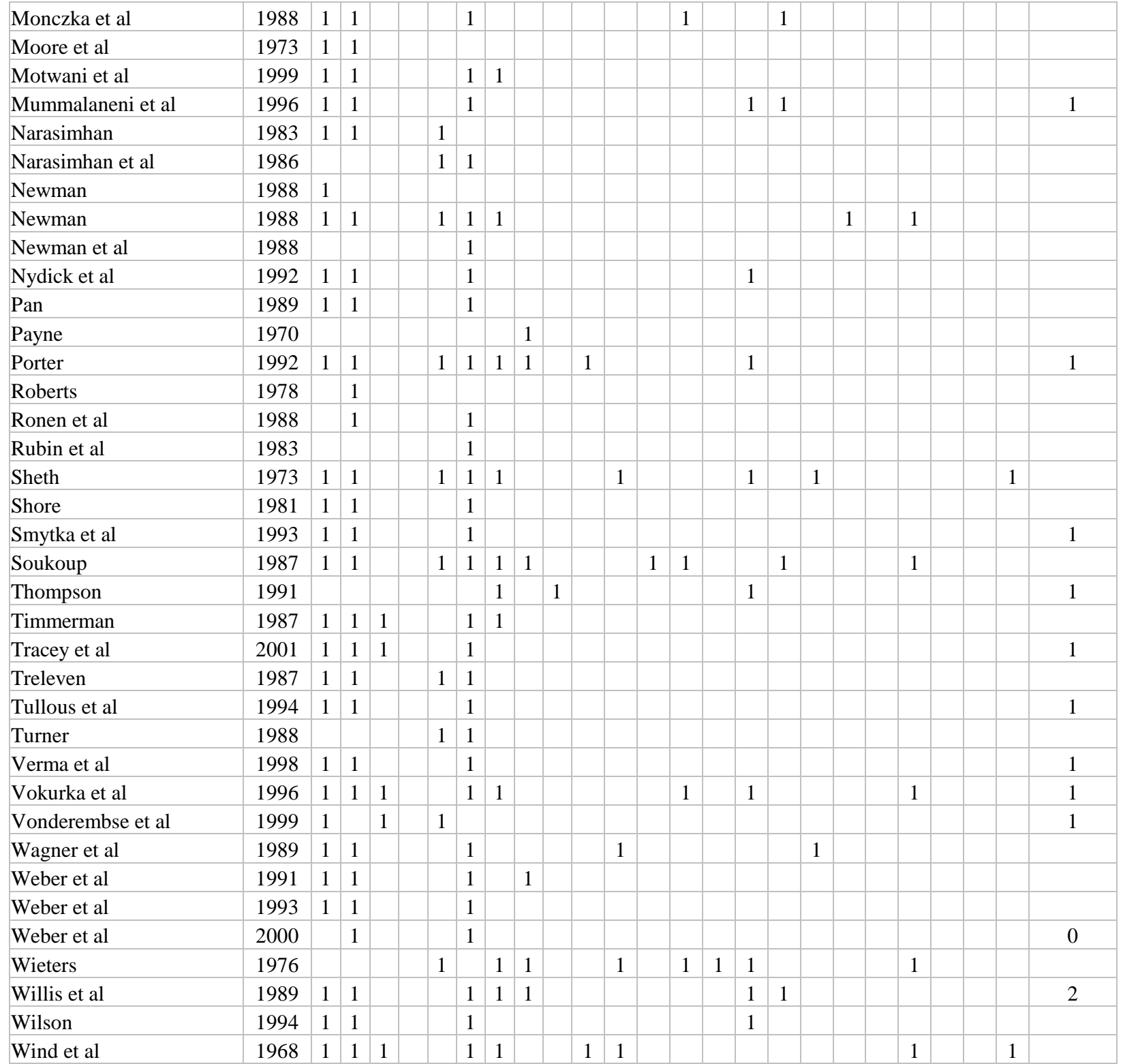

